\title{
Problems in Different Measuring and Assessment the Modulus of Deformation Using the Czech and German Methodologies
}

\author{
M. Lidmila, L. Horníček, H. Krejčiříková, P. Tyc \\ Comparative laboratory and in-situ measurements were used to establish the relationships between the static moduli of deformation \\ calculated under the CLD methodology and the DB methodology. The measurements proved that the moduli of deformation determined in \\ accordance with the two methodologies cannot be substituted for each other.
}

Keywords: Modul of deformation, conventional Trans-European System, the substructure, Classification of Soils, the earth subgrade, the fixed track section, the corridor track, rubber plates, granulated gravel, the correlation coefficient.

\section{Introduction}

While building the fixed track section from Třebovice to Rudoltice in 2005, the substructure was designed in accordance with the regulations in force for DB (German Federal Railways). The requirement for the bearing capacity of the substructure subgrade was $120 \mathrm{MPa}$, i.e. a value greatly exceeding the requirements of SŽDC (Czech Railway Infrastructure Administration) for corridor tracks. Ministry of Transport of the Czech Republic research project No.1F52H/052/130 [1] was therefore charged with investigating the correlations between the static modulus of deformation determined under the regulations of $\check{C} \mathrm{D}$ (Czech Railways) and DB. Comparative measurements were carried out in laboratory conditions in an experimental box (on gravel and granulated gravel) and in in-situ conditions (on sand and soil).

\section{Measurement of moduli of deformation at SŽDC (}

The requirements for the measuring apparatus, a detailed test procedure and its assessment are regulated in instruction ČD S4 Substructure [2] and in standard ČSN 721006 Checking the compaction of soils and fills [3]. At the begining of the measurements, to ensure tight fitting of individual parts of the load device, short-term loading not exceeding $10 \mathrm{~s}$ is activated, which must not generate a pressure on the loaded layer greater than $20 \%$ of the maximum plate load. The initial reading is taken after the load is removed and the path indicators are stabilized. The plate is then gradually loaded in four steps of equal magnitude. For each loading step, the deformation of the subsoil under the plate is recorded. If the change in deformation during 1 minute is less than $0.02 \mathrm{~mm}$, it is considered as stabilized and the next loading step follows. The procedure continues in the same way until the maximum load required for the loaded layer is reached. Later the load plate is relieved in the same steps down to zero load, and the cycle is repeated for the second time.

During the test, the plate load values are read on the load gauge and the plate insertion is read on the path indicators.
The mean load plate insertion values in each loading and load removal step are plotted in a chart expressing the relationship between the specific pressure acting on the load plate and the load plate insertion. The value of the total mean plate insertion from the loading branch of the second cycle is entered in the chart with a simultaneous calculation of the modulus of deformation using general formula:

$$
E=1.5 \frac{p \cdot r}{y}
$$

where $E$ is static modulus of deformation [MPa],

$p \quad$ specific pressure acting on the load plate [MPa],

$r \quad$ load plate radius, i.e. 0.15 [m],

$y \quad$ total mean load plate insertion determined in the loading branch of the second cycle [m].

The specific pressure on the load plate is selected as follows: on earth subgrade $p=0.2 \mathrm{MPa}$ with a loading step of $0.05 \mathrm{MPa}$, for less bearing soils $p=0.1 \mathrm{MPa}$ with a loading step of $0.025 \mathrm{MPa}$; on a structural layer of the substructure body $p=0.2 \mathrm{MPa}$ with a loading step of $0.05 \mathrm{MPa}$; and on the rail bed at sleeper loading area $=0.4 \mathrm{MPa}$ with a loading step of 0.10 MPa (Note: since 1. 1. 2003 the bearing capacity at this level has no longer been assessed). The measurement of the modulus of deformation in the experimental box on the surface of a granulated gravel layer is shown in Fig. 1.

\section{Measurement of moduli of deformation at $\mathrm{DB}$}

The requirements for the measuring apparatus, the detailed test procedure and its assessment are regulated in German standard DIN 18134 Plattendruckversuch [3]. At the begining of the measurement, a preload of ca $0.01 \mathrm{MPa}$ is activated to be removed in about 30 seconds, and the reading on the path indicators is set at $0.00 \mathrm{~mm}$. The test procedure consists of two loading branches and one load removal branch. A plate with a diameter of $300 \mathrm{~mm}$ is loaded until the plate insertion reaches a value of ca $5 \mathrm{~mm}$ or a specific pressure of $0.50 \mathrm{MPa}$. The load is added step by step in at least 6 roughly identical steps. In each loading step, the path indi- 
cators are read at 120 second intervals, and in the case of load-bearing layers this time may be reduced to 60 seconds. When measuring with 3 path indicators, the reading on the first indicator is taken 10 seconds before the waiting time expiry. The path indicators are always read in the same order and at identical time intervals. Load removal is carried out in 3 steps $-50 \%, 25 \%$ and $0 \%$ of the maximum plate load. The second loading branch terminates in the last but one step of the first loading branch.

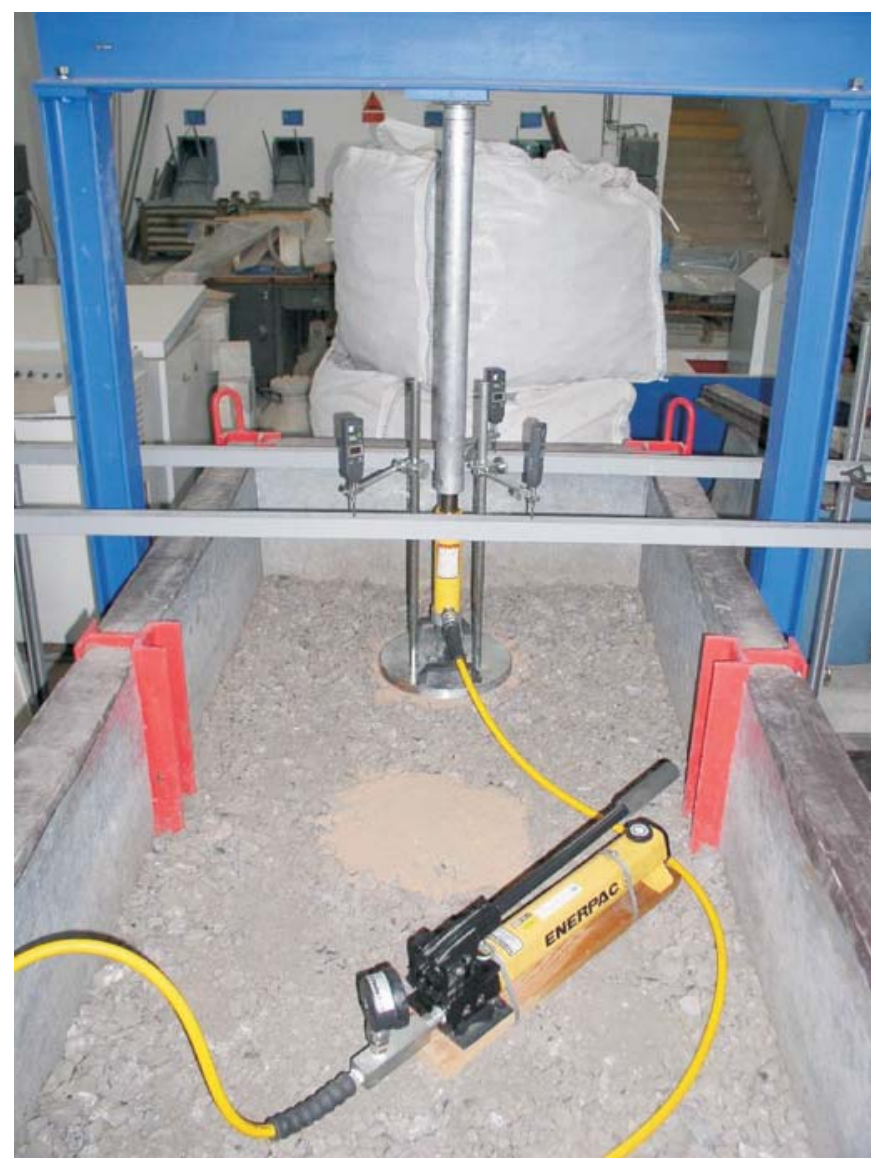

Fig. 1: Measuring the static modulus of deformation on a granulated gravel layer in the experimental box

The modulus of deformation (Verformungsmodul) is calculated from both the first and the second loading branch. It is determined from the loading chart, from the inclination of the secant line between two points given by the value of the 0.3 - and 0.7-multiple of the maximum load, using the general formula:

$$
E_{v}=1.5 \cdot r \cdot \frac{\Delta \sigma}{\Delta s}
$$

where $E_{v}$ is static modulus of deformation [MPa],

$r \quad$ load plate radius, i.e. 0.15 [m],

$y \quad$ total mean load plate insertion determined in the loading branch of the second cycle $[\mathrm{m}]$,

$\Delta \sigma$ difference in the value of the 0.3- and 0.7-multiple of the maximum load [MPa],

$\Delta s$ difference in the load plate insertion between the value of the 0.3 - and 0.7 -multiple of the maximum load [MPa].

\section{Measurement of moduli of deformation on rail bed models}

In order to establish the correlation between the moduli of deformation of rail bed structures determined in accordance with the Czech and German methodologies in laboratory conditions, the experimental box of the Department of Railway Structures of the Faculty of Civil Engineering, CTU in Prague was used. The experimental box consists of welded steel sections and removable walls of wooden planks. The walls of the box walls were lined with a thin galvanized plate to minimize the friction of the model at contacts with the walls of the box. The basic dimensions of the inside space of the experimental box are: length: $2095 \mathrm{~mm}$, width: $990 \mathrm{~mm}$, height: $800 \mathrm{~mm}$. The experimental box also includes a movable frame, which enables load press to be propped while measuring the moduli of deformation on models in the experimental box.

The experimental box was used for experimental monitoring of 4 rail bed models in a 1:1 scale composed of rubber plates simulating earth subgrade with different bearing capacities (10.9 MPa, $25 \mathrm{MPa})$, structural layers of granulated gravel of $0 / 32 \mathrm{~mm}$ grading with different thicknesses $(15 \mathrm{~cm}$, $30 \mathrm{~cm}$ ) and a rail bed of gravel of $32 / 63 \mathrm{~mm}$ grading with a constant thickness of $35 \mathrm{~cm}$. The gravel and granulated gravel were exposed to a grain composition test, which proved that the grain size composition of these materials is suitable for use in rail beds or in structural layers of the substructure body.

The moduli of deformation were determined at three height levels: on a simulated earth subgrade, on a layer of granulated gravel and on a layer of gravel. The individual models were labelled with codes containing information on the thickness of the structural layer in $\mathrm{cm}$, abbreviations of the material used for the structural layer and the approximate bearing capacity of the simulated earth subgrade in MPa (e.g. 15SD E10). Characteristic data for each model is presented in Tab. 1. The model of the 5SD E10 structure in the experimental box is shown in Fig. 2.

Table 1: Labelling of rail bed models and their characteristics

\begin{tabular}{|c|c|c|c|}
\hline $\begin{array}{c}\text { Model } \\
\text { labelling }\end{array}$ & $\begin{array}{c}\text { Earth subgrade } \\
\text { bearing capacity } \\
\text { in MPa }\end{array}$ & $\begin{array}{c}\text { Structural layer } \\
\text { thickness in } \\
\text { mm }\end{array}$ & $\begin{array}{c}\text { Rail bed } \\
\text { thickness } \\
\text { in mm }\end{array}$ \\
\hline 15SD E10 & 10.9 & 150 & 350 \\
\hline 30SD E10 & 10.9 & 300 & 350 \\
\hline 15SD E25 & 25.0 & 150 & 350 \\
\hline 30SD E25 & 25.0 & 300 & 350 \\
\hline
\end{tabular}

The structural layer was composed of either one or two layers, $150 \mathrm{~mm}$ in thickness, and the rail bed consisted of two layers, $175 \mathrm{~mm}$ in thickness. The individual layers were compacted with a special manual vibrating compacting device with a compacting area of $174 \times 174 \mathrm{~mm}$, and each layer was uniformly compacted for 30 minutes along the whole surface of the experimental box. 


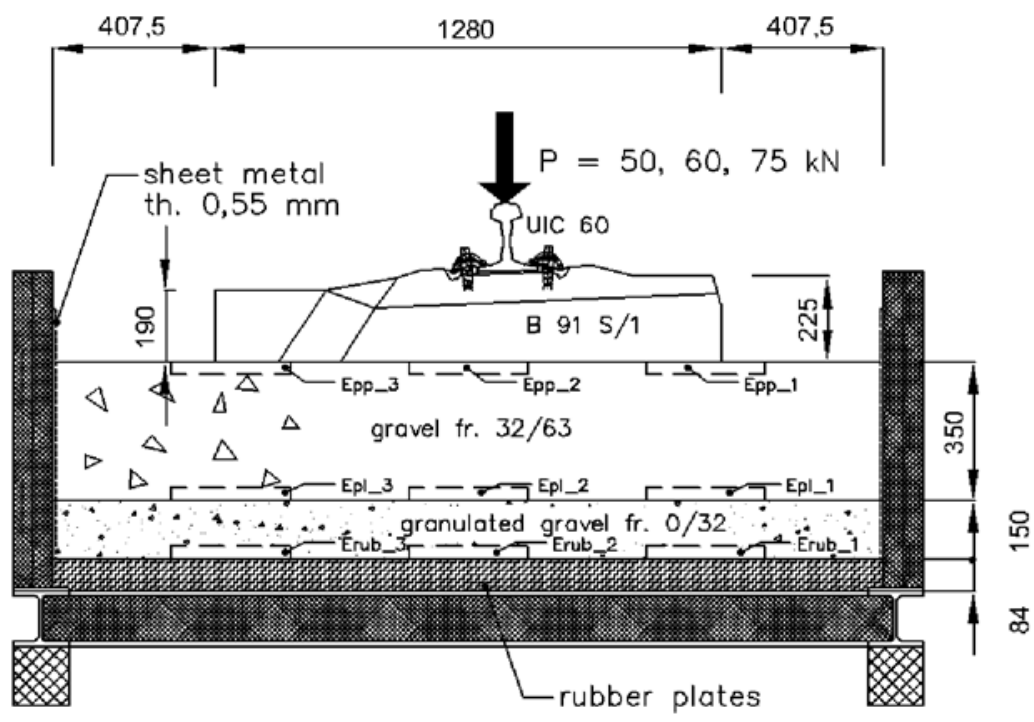

a)

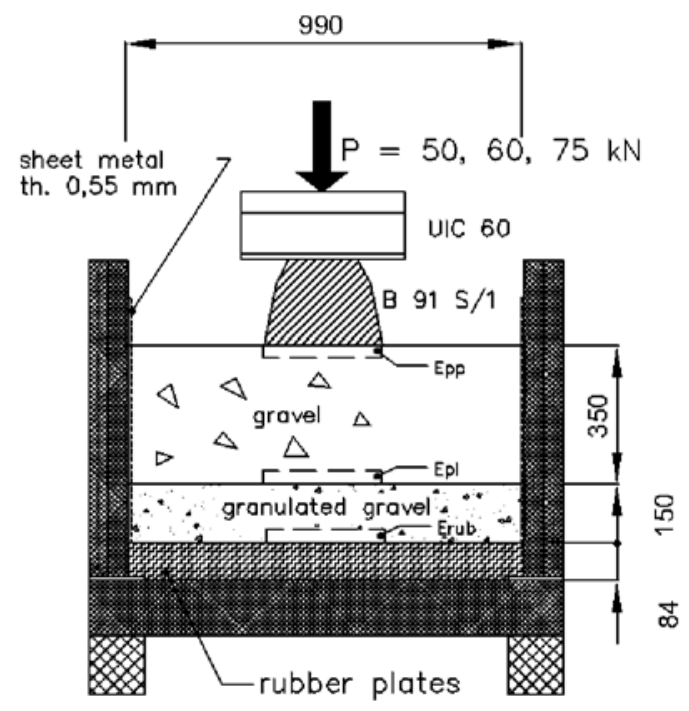

b)

Fig. 2: Rail bed structure model 15SD E10 in the experimental box: a) longitudinal section, b) cross section

\section{Measurements of moduli of deformation on a layer of gravel}

After each model, had been constructed, the three plate load tests on a layer of gravel were performed following the ČD methodology and then, in identical positions, three plate load tests were performed following the DB methodology. This measurement method was selected due to the confined plan of the model. Inaccuracy in determining of the modulus of deformation under the DB methodology, however, will be insignificant. The composition of the 15SD E10 model with schematic positions of the circular load plate is shown in Fig. 2. The determined values of the moduli of deformation are given in Table 2 .

Table 2: Moduli of deformation on a gravel surface for each methodology

\begin{tabular}{|c|c|c|}
\hline \multirow{2}{*}{ Model labelling } & \multicolumn{2}{|c|}{ Mean modulus of deformation in MPa } \\
\cline { 2 - 3 } & ČD methodology & DB methodology \\
\hline 15SD E10 & 63.8 & 71.3 \\
\hline 30SD E10 & 79.4 & 98.3 \\
\hline 15SD E25 & 90.0 & 104.5 \\
\hline 30SD E25 & 103.9 & 117.7 \\
\hline
\end{tabular}

\section{Measurements of moduli of deformation on a layer of granulated gravel}

Once the plate load tests on a layer of gravel were completed, the gravel was removed from each model, and three plate load tests were performed on a layer of granulated gravel under the ČD methodology and subsequently, in identical positions, three plate load tests were performed under the DB methodology. The determined values of the moduli of deformation are given in Table 3.

Table 3: Moduli of deformation on a granulated gravel surface for each methodology

\begin{tabular}{|c|c|c|}
\hline \multirow{2}{*}{ Model labelling } & \multicolumn{2}{|c|}{ Mean modulus of deformation in MPa } \\
\cline { 2 - 3 } & ČD methodology & DB methodology \\
\hline 15SD E10 & 26.1 & 23.0 \\
\hline 30SD E10 & 53.3 & 48.9 \\
\hline 15SD E25 & 50.1 & 44.1 \\
\hline 30SD E25 & 82.9 & 86.4 \\
\hline
\end{tabular}

\section{Measurements of moduli of deformation on sand}

The location selected for in-situ measurements of the moduli of deformation was the Klíčany sand pit, where sand with fine soil admixtures is quarried. The measurements were carried out at two points (field No. 1 and field No. 2) with the natural placement of sand layers showing no significant disintegration due to the extraction machinery. The counterweight used during the measurement of the static moduli of deformation was a loaded lorry. In all, six plate load tests were performed using the ČD methodology and six plate load tests using the DB methodology. Once the plate load tests were completed, holes were dug at the measurement points to a depth of $1.0 \mathrm{~m}$. These dug holes served for taking disintegrated samples for geotechnical laboratory analyses which proved that the tested layer of sand can be classified under ČSN 721002 [5] as sand with fine soil admixtures (S3 S-F) with a mean natural moisture content of $7.8 \%$ in field No. 1 and $5.5 \%$ in field No. 2. The determined values of the moduli of deformation are given in Table 4. Fig. 3 shows the modulus of deformation being measured on a layer of sand in the Klíčany sand pit. 


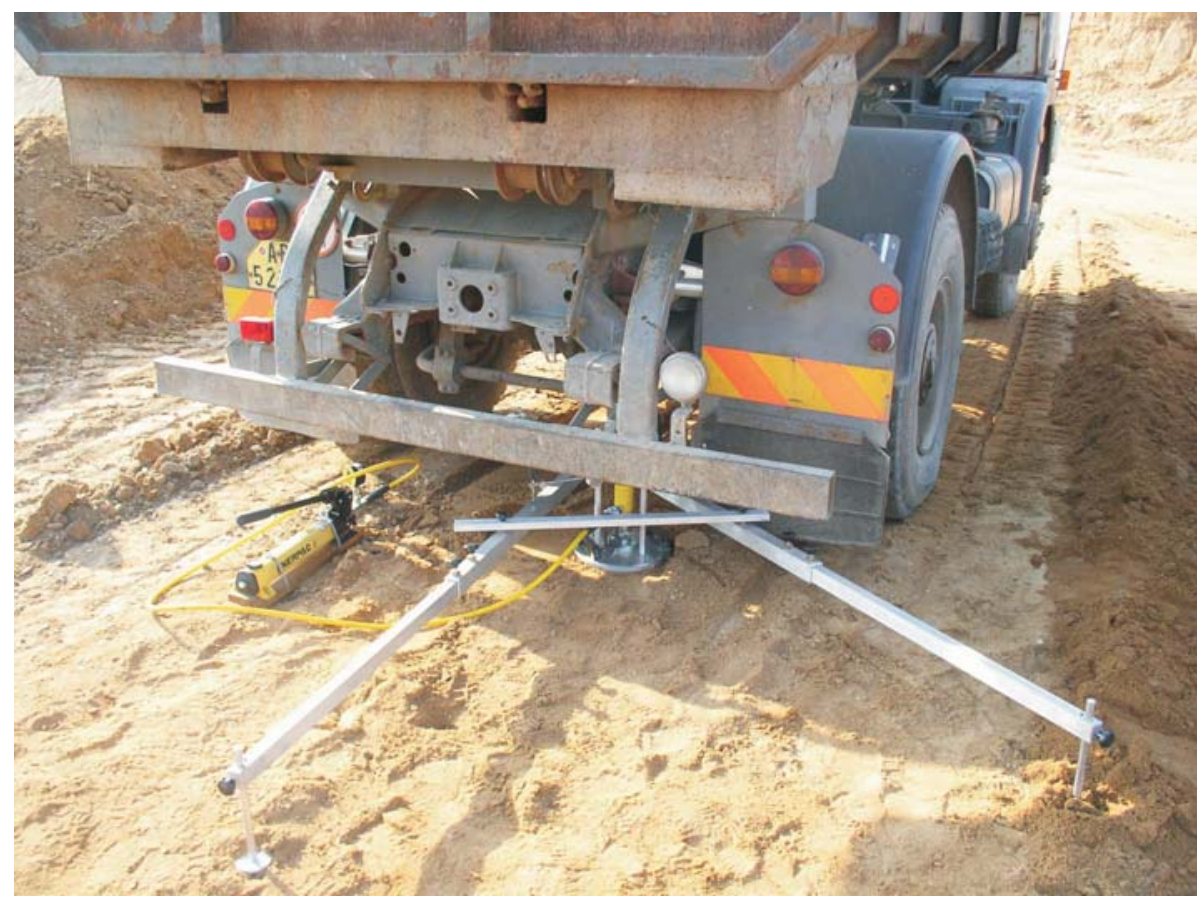

Fig. 3: Static modulus of deformation being measured on a layer of sand in the Klíčany sand pit

Table 4: Moduli of deformation on sand for each methodology

\begin{tabular}{|c|c|c|c|}
\hline \multirow{2}{*}{$\begin{array}{c}\text { Field } \\
\text { labelling }\end{array}$} & \multirow{2}{*}{$\begin{array}{c}\text { Mean natural } \\
\text { moisture } \\
\text { content in } \%\end{array}$} & $\begin{array}{c}|c| \\
\text { Mean modulus of deformation } \\
\text { in MPa }\end{array}$ \\
\cline { 3 - 4 } & & $\begin{array}{c}\text { ČD } \\
\text { methodology }\end{array}$ & $\begin{array}{c}\text { DB } \\
\text { methodology }\end{array}$ \\
\hline Field No. 1 & 8.7 & 82.2 & 136.8 \\
\hline Field No. 2 & 5.5 & 38.7 & 67.4 \\
\hline
\end{tabular}

\section{Measurements of moduli of deformation on soil}

The location selected for in-situ measurements of the moduli of deformation was the construction site of an embankment at Svojšovice as part of corridor IV within the Říčany - Stránčice section. The measurement was carried out on a compacted layer of highly non-homogeneous material compacted at two points (field No. 1 and field No. 2). The counterweight used was a flat vibratory roller or a loaded lorry. In all, six plate load tests were performed using the ČD methodology and six plate load tests using the DB methodology. Once the plate load tests were completed, holes were dug at the measurement points to a depth of $0.5 \mathrm{~m}$. These dug holes served for taking disintegrated samples for geotechnical laboratory analyses which proved that the layer of soil can be classified under ČSN 721002 [5] as dirty gravel (G5 GC) to gravel with fine soil admixtures (G3 GF) with a mean natural moisture content of $12.7 \%$ in field No. 1, while the soil layer in field No. 2 is composed of gravely clay (F2 CG) to gravely loam (F1 MG) with a mean moisture
Table 5: Moduli of deformation on soil for each methodology

\begin{tabular}{|c|c|c|c|}
\hline \multirow{2}{*}{$\begin{array}{l}\text { Field } \\
\text { labelling }\end{array}$} & \multirow{2}{*}{$\begin{array}{c}\text { Mean natural } \\
\text { moisture } \\
\text { content in } \%\end{array}$} & \multicolumn{2}{|c|}{$\begin{array}{c}\text { Mean modulus of deformation } \\
\text { in } \mathrm{MPa}\end{array}$} \\
\hline & & $\begin{array}{c}\check{C} \mathrm{D} \\
\text { methodology }\end{array}$ & $\begin{array}{c}\text { DB } \\
\text { methodology }\end{array}$ \\
\hline Field No. 1 & 12.7 & 92.1 & 66.3 \\
\hline Field No. 2 & 15.8 & 56.0 & 45.6 \\
\hline
\end{tabular}

content of $15.8 \%$. The values of the moduli of deformation are shown in Table 5 .

\section{Correlation coefficients}

In order to express the relationship of the moduli of deformation determined under the ČD methodology and under the DB methodology, the correlation coefficients were calculated from the formula:

$$
k=\frac{E_{\mathrm{DB}}}{E_{\check{\mathrm{C}} \mathrm{D}}},
$$

where $k$ is correlation coefficient [-],

$E_{\mathrm{DB}}$ modulus of deformation determined under the German methodology from the second loading branch $[\mathrm{MPa}]$,

$E_{\check{C} \mathrm{D}}$ modulus of deformation determined under the Czech methodology [MPa].

The correlation coefficients of the moduli of deformation on a layer of gravel are shown in Table 6, and on a layer of granulated gravel in Table 7. 
Table 6: Correlation coefficients on a layer of gravel

\begin{tabular}{|c|c|c|}
\hline $\begin{array}{c}\text { Model } \\
\text { labelling }\end{array}$ & $\begin{array}{c}\text { Mean correlation } \\
\text { coefficient " } k \text { " }\end{array}$ & $\begin{array}{c}\text { Total mean correlation } \\
\text { coefficient " } k \text { " }\end{array}$ \\
\hline 15SD E10 & 1.12 & \multirow{2}{*}{1.17} \\
\hline 30SD E10 & 1.24 & \\
\hline 15SD E25 & 1.16 & \\
\hline 30SD E25 & 1.13 & \\
\hline
\end{tabular}

Table 7: Correlation coefficients on a layer of granulated gravel

\begin{tabular}{|c|c|c|}
\hline $\begin{array}{c}\text { Model } \\
\text { labelling }\end{array}$ & $\begin{array}{c}\text { Mean correlation } \\
\text { coefficient " } k \text { ” }\end{array}$ & $\begin{array}{c}\text { Total mean correlation } \\
\text { coefficient " } k \text { ” }\end{array}$ \\
\hline 15SD E10 & 0.88 & \\
\hline 30SD E10 & 0.92 & \multirow{2}{*}{0.94} \\
\hline 15SD E25 & 0.88 & \\
\hline 30SD E25 & 1.04 & \\
\hline
\end{tabular}

The correlation coefficients of the moduli of deformation on sand are given in Table 8 and on soil in Table 9 .

Table 8: Correlation coefficients on sand

\begin{tabular}{|c|c|c|c|}
\hline $\begin{array}{c}\text { Model } \\
\text { labelling }\end{array}$ & $\begin{array}{c}\text { Natural } \\
\text { moisture } \\
\text { content in } \%\end{array}$ & $\begin{array}{c}\text { Mean } \\
\text { correlation } \\
\text { coefficient " } k \text { " }\end{array}$ & $\begin{array}{c}\text { Total mean } \\
\text { correlation } \\
\text { coefficient " } k \text { " }\end{array}$ \\
\hline Field No. 1 & 8.7 & 1.66 & \multirow{2}{*}{1.70} \\
\hline Field No. 2 & 5.5 & 1.74 & \\
\hline
\end{tabular}

Table 9: Correlation coefficients on soil

\begin{tabular}{|c|c|c|c|}
\hline $\begin{array}{c}\text { Model } \\
\text { labelling }\end{array}$ & $\begin{array}{c}\text { Natural } \\
\text { moisture } \\
\text { content in } \%\end{array}$ & $\begin{array}{c}\text { Mean } \\
\text { correlation } \\
\text { coefficient “ } k \text { " }\end{array}$ & $\begin{array}{c}\text { Total mean } \\
\text { correlation } \\
\text { coefficient " } k \text { ” }\end{array}$ \\
\hline Field No. 1 & 12.7 & 0.72 & \multirow{2}{*}{0.76} \\
\hline Field No. 2 & 15.8 & 0.81 & \\
\hline
\end{tabular}

\section{Conclusion}

The correlation coefficients determined in our experiment lead to the following conclusions:

1. The ČD and DB methodologies for measuring the static moduli of deformation apply the same testing apparatus (a circular load plate with a diameter of $30 \mathrm{~cm}$ ), but the prescribed plate load loading is different and so is the calculation procedure for the static modulus of deformation.

2. Comparative measurements of static moduli of deformation show that the correlation dependency emerging from the determined moduli of deformation $k=E_{\mathrm{DB}} / E_{\mathrm{C}} \mathrm{D}$ shows considerable differences both for different materials and for multi-layer systems of various materials. For example, the measurements revealed fluctuations in correlation coefficient " $k$ " in the range of 0.76 to 1.70 . In designing the track body, the values of the static moduli of deformation as determined under the ČD methodology and the DB methodology cannot be substituted for each other.

3. In designing the rail bed on SŽDC tracks, the requirements for the load-bearing capacity of individual layers must be respected as regulated in instruction ČD S4 Substructure. The requirements given by instruction ČD S4 Substructure cannot be substituted for the requirements given by instruction DS 836 Vorschrift für Erdbauwerke applied by DB.

4. In the case of a potential change in the C̆D methodology for measuring of the static modulus of deformation (e.g. by taking over a uniform European standard), instruction ČD S4 Substructure, ČSN 721006 Checking the compaction of soils and fills and other related regulations would have to undergo considerable modifications.

\section{Acknowledgment}

This paper was written within the research project No. 1F52H/052/130 funded by Ministry of Transport of the Czech Republic.

\section{References}

[1] Krejčiříková, H., Tyc, P., Lidmila, M., Horníček, L., Voř́šek, P., et al.: Methodology of Transitional Parameters for the Construction of Substructure and Tracks of the Conventional Trans-European System. Research reports of project 1F52H/052/130, Faculty of Civil Engineering, CTU in Prague, Department of Railway Structures, 2005 and 2006.

[2] Instruction ČD S4 Substructure, 1997 (in force since 1. 7. 1998).

[3] ČSN 721006 Checking the Compaction of Soils and Fills. Český normalizační institut, 1998.

[4] DIN 18134 Plattendruckversuch. Deutsches Institut für Normung e. V., 1993.

[5] ČSN 721002 Classification of Soils for Transportation Structures. Český normalizační institut, 1993.

Ing. Martin Lidmila, Ph.D.

e-mail: lidmila@fsv.cvut.cz

Ing. Leoš Horníček, Ph.D.

e-mail: leos.hornicek@fsv.cvut.cz

Doc. Ing. Hana Krejčiříková, CSc.

phone: +420224354756

e-mail: krejcirikova@fsv.cvut.cz

Prof. Ing. Petr Tyc, DrSc.

e-mail: petr.tyc@fsv.cvut.cz

Department of Railway Structures

Czech Technical University in Prague

Faculty of Civil Engineering

Thákurova 7

16629 Praha 6, Czech Republic 